Web Jurnal:

Kementerian

Perındustrian

REPUBLIK INDONESIA http://ejournal.kemenperin.go.id/jli

Jurnal Litbang Industri

p-ISSN: 2252-3367 | e-ISSN: 2502-5007 |

\title{
Biosorben cangkang pensi (Corbicula moltkiana) sebagai penyerap zat warna metanil yellow ditinjau dari pH dan model kesetimbangan adsorpsi
}

\section{Pensi shell (Corbicula moltkiana)as a biosorbent for metanil yellow dyes removal: pH and equilibrium model evaluation}

Rahmiana Zein*1, Putri Ramadhani², Hermansyah Aziz ${ }^{3}$, Refilda Suhaili ${ }^{4}$

1 Laboratorium Kimia Analisis Lingkungan, Jurusan Kimia FMIPA Universitas Andalas

Limau Manis, Pauh, Kota Padang, Sumatera Barat, Indonesia

2 Program Pascasarjana, Jurusan Kimia FMIPA Universitas Andalas

Limau Manis, Pauh, Kota Padang, Sumatera Barat, Indonesia

3 Laboratorium Kimia Fisika, Jurusan Kimia FMIPA Universitas Andalas

Limau Manis, Pauh, Kota Padang, Sumatera Barat, Indonesia

4 Laboratorium Kimia Terapan, Jurusan Kimia FMIPA Universitas Andalas

Limau Manis, Pauh, Kota Padang, Sumatera Barat, Indonesia

* e-mail: rzein@sci.unand.ac.id

\begin{tabular}{|c|c|}
\hline INFO ARTIKEL & ABSTRAK \\
\hline Sejarah artikel: & Penelitian cangkang pensi (Corbicula moltkiana) sebagai penyerap zat warna metanil \\
\hline Diterima: & yellow telah dilakukan dengan sistem batch. Kondisi optimum penyerapan terjadi pada \\
\hline 1 Februari 2019 & pH 4 dan konsentrasi awal $100 \mathrm{mg} / \mathrm{L}$. Proses adsorpsi terjadi mengikuti model isoterm \\
\hline Direvisi: & Langmuir dengan nilai $\mathrm{R}^{2}$ adalah 0,886 pada monolayer dengan kapasitas adsorpsi \\
\hline 23 April 2019 & maksimum $\left(\mathrm{q}_{\max }\right)$ diperoleh $2,591 \mathrm{mg} / \mathrm{g}$. Hasil analisis gugus fungsi cangkang pensi \\
\hline Diterbitkan: & dengan FTIR menunjukkan adanya interaksi antara molekul zat warna metanil yellow dan \\
\hline 28 Jun1 2019 & gugus fungsi. Analisis morfologi permukaan cangkang pensi menggunakan SEM \\
\hline $\begin{array}{l}\text { Kata kunci: } \\
\text { adsorpsi; }\end{array}$ & $\begin{array}{l}\text { yellow. Cangkang pensi dapat digunakan sebagai bahan penyerap zat warna metanil } \\
\text { yellow di dalam larutan. }\end{array}$ \\
\hline
\end{tabular}

isoterm;

metanil yellow;

batch

Keywords:

adsorption;

pensi shell;

isotherm;

metanil yellow;

batch

\begin{abstract}
The study of the Pensi Shell (Corbicula moltkiana) to adsorb metanil yellow (MY) dyes has been investigated. This study was determined by batch system. The optimum conditions of metanil yellow dyes adsorption occurred at $\mathrm{pH} 4$ and initial concentration $100 \mathrm{mg} / \mathrm{L}$. The adsorption process was properly described by Langmuir isotherm model which was indicated by the value of $R^{2}=0,886$. This confirmed that the adsorption process was monolayer with maximum adsorption capacity $\left(q_{\max }\right)$ was $2,591 \mathrm{mg} / \mathrm{g}$. Functional groups analysis by FTIR showed the interactions MY molecule on pensi shell functional groups. Analysis of morphology surface of pensi shell by SEM indicated that the pore was filled by MY molecules. Pensi shell could be used as adsorbent of metanil yellow dyes in aqueous solution.
\end{abstract}

(C) 2019 Penulis. Dipublikasikan oleh Baristand Industri Padang. Akses terbuka dibawah lisensi CC BY-NC-SA

\section{Pendahuluan}

Penanganan sistem pembuangan limbah industri yang tidak terkontrol menyebabkan lingkungan tercemar oleh bahan-bahan berbahaya seperti zat warna. Pembuangan limbah zat warna secara berlebihan berasal dari aktivitas industri tekstil, kertas, pupuk, cat, dan pigmen (Sulyman et al., 2017). Aktivitas industri ini sering melepaskan limbah zat warna dalam konsentrasi tinggi yang dapat masuk melalui rantai makanan sehingga berdampak buruk bagi kesehatan manusia (Contreras et al., 2012). 
Molekul zat warna terdiri dari dua gugus yaitu kromofor dan auksokrom. (Saba et al., 2016). Salah satu jenis gugus kromofor yaitu gugus azo $(-\mathrm{N}=\mathrm{N}-)$. Jenis zat warna yang mengandung gugus azo ini merupakan zat warna komersial dan serbaguna yang diaplikasikan sekitar $70 \%$ dalam industri di seluruh dunia (Benkhaya et al., 2017). Namun, keberadaan gugus fungsi ini menyebabkan zat warna sulit terdegradasi secara alami di lingkungan sehingga berdampak buruk pada organisme air dengan menghalangi sinar matahari, memperlambat aktivitas fotosintesis dan menciptakan kondisi anaerob yang membatasi pertumbuhan biota air (Daniel et al., 2013). Selain itu, juga berdampak buruk terhadap kesehatan manusia seperti alergi, iritasi kulit, disfungsi ginjal, hati, otak, reproduksi, dan sistem syaraf (Zein et al., 2015).

Metanil yellow merupakan salah satu jenis zat warna yang mengandung gugus azo dan sering digunakan dalam proses pencelupan serat, nilon, wol dan sutra. Aplikasi zat warna azo yang cukup tinggi di industri jika tidak dikelola dengan tepat tentu akan berdampak buruk terhadap kesehatan dan lingkungan. Maka dari itu, perlu dilakukan pengolahan limbah terlebih dahulu sebelum dibuang ke lingkungan agar pencemaran lingkungan dapat diminimalisir.

Beberapa metode konvensional telah digunakan untuk pengolahan limbah zat warna seperti koagulasi, elektrokimia, reverse osmosis, filtrasi nano, dan lain-lain (Gupta and Suhas, 2009). Namun metode tersebut memiliki kekurangan seperti kurang efisien dan mahal dalam proses pengolahannya (Sulyman et al., 2017). Salah satu proses pengolahan limbah zat warna yang saat ini bekembang yaitu metode adsorpsi. Metode ini paling banyak digunakan karena metode ini aman, tidak memberikan efek samping yang membahayakan kesehatan, peralatan yang digunakan sederhana dan murah, mudah pengerjaannya, dapat didaur ulang, efisien dan ekonomis (Sivakumar and Palanisamy, 2009). Metode adsorpsi yang saat ini sedang berkembang yaitu biosorpsi. Metode ini menggunakan adsorben alami yang berasal dari tumbuhan maupun hewan (biosorben) seperti limbah pertanian dan perikanan yang lebih ramah lingkungan, efisiensi tinggi dan mudah diperoleh sehingga dapat mengurangi limbah padat organik (Zein et al., 2015, 2010).

Beberapa penelitian mengenai pemanfaatan biosorben dari limbah padat organik untuk menyerap berbagai zat warna telah dilakukan seperti serbuk gergaji (Sushmita and Chattopadhyaya, 2017), biji buah apricot (Albroomi et al., 2017), biji manga (Alencar et al., 2012), biji dawet (Rehman et al., 2012), biji jeruk(Jeyajothi, 2014), biji durian (Chaidir et al., 2015b), biji sirsak (Chaidir et al., 2015a; Fauzia et al., 2015), kulit melon (Djelloul and Hamdaoui, 2015), biji rambutan (Zein et al., 2015), tulang ikan (Ribeiro et al., 2015), siput laut (Messaoudi et al., 2016), cangkang kepiting (Ravi et al., 2015) dan kulit udang (Khedr et al., 2013).

Pensi (Corbicula moltkiana) adalah sejenis kerang air tawar tetapi memiliki ukuran tubuh lebih kecil. Habitat binatang ini sudah ada yang menyebar ke sungai-sungai kecil di sekitar Danau Maninjau dan Singkarak (Zeswita and Safitri, 2015). Berdasarkan hasil penelitian sebelumnya membuktikan bahwa cangkang pensi mengandung oksida logam dan gugus fungsi (hidroksil, karboksil, karbonil, amina, dan lainnya) yang akan berinteraksi dengan molekul zat warna dan ion logam (Zein et al., 2018). Oleh karena itu, penelitian ini mempelajari kemampuan cangkang pensi sebagai adsorben zat warna metanil yellow dengan metode batch. Hasil penelitian ini diharapkan bermanfaat sebagai bahan acuan dan informasi penting dalam penelitian lanjutan tentang pemanfaatan limbah perikanan sebagai penyerap zat warna dalam limbah industri.

\section{Metode}

Bahan yang digunakan dalam penelitian ini adalah cangkang pensi (Corbicula moltkiana) yang berasal dari Danau Singkarak Sumatera Barat, zat warna metanil yellow (MY), akuades, $\mathrm{HNO}_{3}$ p.a (Merck), $\mathrm{NaOH}$ teknis (Merck), Asam Sitrat $\left(\mathrm{C}_{6} \mathrm{H}_{8} \mathrm{O}_{7}\right)$ (Merck), Natrium Sitrat dihidrat $\left(\mathrm{C}_{6} \mathrm{H}_{5} \mathrm{Na}_{3} \mathrm{O}_{7} .2 \mathrm{H}_{2} \mathrm{O}\right)$ (Merck), Asam Asetat $\left(\mathrm{CH}_{3} \mathrm{COOH}\right)$ (Merck), Natrium Asetat $\left(\mathrm{CH}_{3} \mathrm{COONa}\right)$ (Merck), Natrium Pospat monobasic $\left(\mathrm{NaH}_{2} \mathrm{PO}_{4}\right)$ (Merck), Natrium Pospat dibasic $\left(\mathrm{Na}_{2} \mathrm{HPO}_{4}\right)$ (Merck) dan kertas saring.

Alat yang digunakan dalam penelitian ini adalah neraca analitik (Kern \& Sohn $\mathrm{GmbH}$ ), pH meter (Metrohm), rotary shaker (Edmun Buhler 7400 Tubingen), oven (Memmert), crusher (Fritsch, Germany), mortar grinding (Fritsch, Germany), FTIR (Unican Mattson Mod 7000 FTIR), SEM (Hitachi S3400N), XRF (PANalytical Epsilon 3), XRD (PANalytical XPERT-PRO), Spektrofotometer UV-Vis (Genesys 20 Thermo Scientific), dan peralatan gelas kimia lainnya.

\subsection{Persiapan biosorben}

Cangkang Pensi (Corbicula moltkiana) dicuci dengan air, dikeringkan pada suhu kamar, digiling dan diayak (ukuran partikel $\leq 160 \mu \mathrm{m}$ ). Kemudian, $25 \mathrm{~g}$ serbuk cangkang pensi diaktivasi dengan merendam serbuk dalam $100 \mathrm{~mL} \mathrm{HNO}_{3}$ 0,01 M selama 3 jam, setelah itu dicuci dengan akuades hingga $\mathrm{pH}$ netral dan kemudian dikering-anginkan (Zein et al., 2018).

\subsection{Persiapan larutan metanil yellow}

Larutan stok zat warna metanil yellow $1000 \mathrm{mg} / \mathrm{L}$ dibuat dengan melarutkan $0,25 \mathrm{~g}$ zat warna metanil yellow (MY) dalam $250 \mathrm{~mL}$ akuades. Larutan standar dibuat dengan pengenceran zat warna metanil yellow pada berbagai konsentrasi (5-150 mg/L) (Zein et al., 2015).

\subsection{Penentuan nilai $\mathrm{pH}$ muatan titik nol $\left(\mathrm{pH}_{\mathrm{pzc}}\right)$}

Penentuan nilai $\mathrm{pH}_{\mathrm{pzc}}$ dilakukan dengan mengontakkan 0,1 gram biosorben dengan $50 \mathrm{~mL} \mathrm{KCl}$ 0,1 M. pH awal disesuaikan dari nilai $\mathrm{pH} 1$ hingga 8 dengan penambahan $\mathrm{HNO}_{3}$ atau NaOH. Kemudian diaduk menggunakan shaker selama 24 jam. Nilai pH akhir larutan dicatat dan perbedaan antara nilai $\mathrm{pH}$ awal 
dan akhir, $\Delta \mathrm{pH}\left(\mathrm{pH}_{\mathrm{f}}-\mathrm{pH}_{\mathrm{i}}\right)$, diplot versus $\mathrm{pH}_{\mathrm{i}}$. Titik perpotongan kurva ini menghasilkan titik muatan nol $\left(\mathrm{pH}_{\mathrm{pzc}}\right)$ (Reddy et al., 2012).

\subsection{Studi biosorpsi}

Penelitian biosorpsi dengan metode batch dilakukan untuk menyelidiki pengaruh $\mathrm{pH}$ (3-8) dan konsentrasi awal zat warna (15-150 mg/L). $\mathrm{pH}$ larutan diatur dengan menambahkan $\mathrm{HNO}_{3}$ atau $\mathrm{NaOH}$ dan larutan buffer pada $\mathrm{pH}$ larutan yang sesuai yang ditempatkan dalam erlenmeyer $25 \mathrm{~mL}$. Erlenmeyer diletakkan pada shaker dengan kecepatan pengadukan $100 \mathrm{rpm}$ selama 90 menit. Kemudian larutan dipisahkan dari biosorben dengan menggunakan kertas saring. Setelah itu, konsentrasi akhir ditentukan dengan menggunakan spektrofotometer UV-Vis pada panjang gelombang 435 $\mathrm{nm}$. Kapasitas adsorpsi biosorben (q, mg/g) dihitung dengan persamaan 1 .

$$
q=\frac{\left(c_{e}-c_{0}\right) V}{m}
$$

di mana $\mathrm{C}_{0}$ adalah konsentrasi awal zat warna; $\mathrm{C}_{\mathrm{e}}$ adalah konsentrasi zat warna dalam keadaan kesetimbangan dalam larutan $(\mathrm{mg} / \mathrm{L}) ; \mathrm{V}$ adalah volume larutan (L); $\mathrm{m}$ adalah jumlah biomassa (g) (Chaidir et al., 2015b).

\subsection{Penentuan isoterm adsorpsi}

Isoterm adsorpsi merupakan pendekatan yang sangat penting untuk menggambarkan bagaimana adsorbat didistribusikan antara fase cair dan padat. Dalam penelitian ini, model isoterm Langmuir dan Freundlich digunakan untuk menggambarkan data kesetimbangan adsorpsi. Persamaan isoterm adsorpsi Langmuir dapat dituliskan sesuai persamaan 2 .

$$
\frac{1}{q_{e}}=\frac{1}{k_{L} q_{m} C_{e}}
$$

Dimana $\mathrm{C}_{\mathrm{e}}$ adalah konsentrasi zat warna dalam keadaan kesetimbangan dalam larutan $(\mathrm{mg} / \mathrm{L}), \quad \mathrm{q}_{\mathrm{m}}$ adalah kapasitas adsorpsi monolayer maksimum biosorben $(\mathrm{mg} / \mathrm{g}), \quad \mathrm{q}_{\mathrm{e}}$ adalah kapasitas penyerapan saat kesetimbangan $(\mathrm{mg} / \mathrm{g})$ dan $\mathrm{K}_{\mathrm{L}}$ adalah konstanta adsorpsi Langmuir (L/mg) yang berhubungan dengan energi bebas adsorpsi.

Isoterm adsorpsi Langmuir mempunyai karakteristik tersendiri dalam menentukan baik atau tidaknya suatu adsorpsi yang dinyatakan sebagai parameter kesetimbangan $\left(\mathrm{R}_{\mathrm{L}}\right)$ yang dinyatakan oleh Persamaan 3:

$$
\mathrm{R}_{\mathrm{L}}=\frac{1}{1+\left(\mathrm{K}_{\mathrm{L}} \times \mathrm{C}_{0}\right)}
$$

Jika $R_{L}>1$, proses adsorpsi tidak menguntungkan, jika $0<\mathrm{R}_{\mathrm{L}}<1$, proses adsorpsi menguntungkan, jika $\mathrm{R}_{\mathrm{L}}=1$, proses adsorpsi linier, sedangkan $\mathrm{R}_{\mathrm{L}}=0$, proses adsorpsi irreversibel (Inyinbor et al., 2015).
Persamaan model isoterm Freundlich diungkapkan seperti persamaan 4 .

$$
\log \mathrm{q}_{\mathrm{a}}=\log \mathrm{K}_{\mathrm{f}}+\frac{1}{\mathrm{n}} \log \mathrm{C}_{\mathrm{a}}
$$

di mana $\mathrm{q}_{\mathrm{e}}$ adalah jumlah adsorbat pada adsorben pada kesetimbangan $(\mathrm{mg} / \mathrm{g}), \mathrm{C}_{\mathrm{e}}$ adalah konsentrasi adsorbat dalam larutan pada kesetimbangan $(\mathrm{mg} / \mathrm{L}) . \mathrm{K}_{\mathrm{f}}$ dan $\mathrm{n}$ adalah konstanta freundlich.

\section{Hasil dan pembahasan}

\subsection{Karakterisasi biosorben}

Karakterisasi cangkang pensi menggunakan Fourier Transform Infra Red (FTIR) dilakukan pada kisaran angka gelombang $4000-400 \mathrm{~cm}^{-1}$. Analisis spektra FTIR penting dilakukan untuk mengidentifikasi gugus-gugus fungsi dari cangkang pensi yang terlibat dalam proses adsorpsi zat warna metanil yellow (MY) dan untuk memprediksi mekanisme penyerapan antara cangkang pensi dengan MY.

Berdasarkan Gambar 1 dapat dilihat bahwa cangkang pensi mengandung beberapa jenis gugus fungsi. Pada cangkang pensi sebelum penyerapan muncul puncak pada angka gelombang $3739 \mathrm{~cm}^{-1}$ yang menunjukkan keberadaan gugus O-H, gugus C-H stretching pada 2924 $\mathrm{cm}^{-1}$, gugus $\mathrm{C}=\mathrm{O}$ (karboksil) pada $2518 \mathrm{~cm}^{-1}$, gugus Si$\mathrm{H}$ pada $2330 \mathrm{~cm}^{-1}$, gugus $\mathrm{C} \equiv \mathrm{C}$ alkyne pada $2182 \mathrm{~cm}^{-1}$ dan gugus $\mathrm{C}=\mathrm{O}$ (karbonil) dalam amida pada $1782 \mathrm{~cm}^{-1}$. Munculnya puncak pada angka gelombang $1461 \mathrm{~cm}^{-1}$ yaitu gugus $\mathrm{C}=\mathrm{O}$ stretching dan gugus $\mathrm{C}-\mathrm{O}$ stretching pada $1083 \mathrm{~cm}^{-1}, 852 \mathrm{~cm}^{-1}$ dan $706 \mathrm{~cm}^{-1}$ menunjukkan puncak khas yang mewakili $\mathrm{CO}_{3}{ }^{2-}$ dari senyawa aragonit $\left(\mathrm{CaCO}_{3}\right)$ (Elamari et al., 2017; Islam et al., 2012).

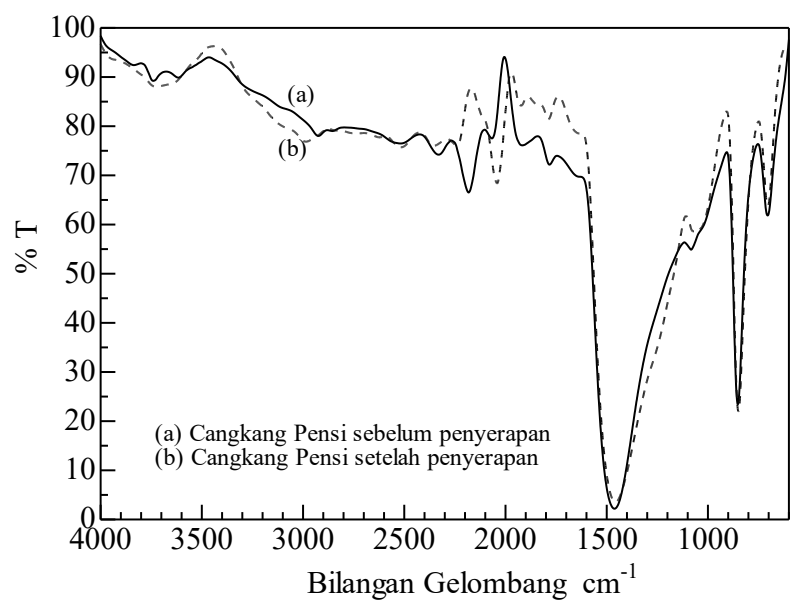

Gambar 1. Spektrum FTIR cangkang pensi sebelum penyerapan zat warna metanil yellow (a) dan setelah penyerapan zat warna metanil yellow (b).

Spektrum FTIR menunjukkan pergeseran angka gelombang setelah proses biosorpsi seperti pada gugus fungsi $\mathrm{O}-\mathrm{H}$, gugus fungsi $\mathrm{C}-\mathrm{H}$, gugus fungsi $\mathrm{Si}-\mathrm{H}$, gugus fungsi $\mathrm{C}=\mathrm{O}$ karboksil gugus fungsi $\mathrm{C} \equiv \mathrm{C}$ alkyne) dan gugus fungsi $\mathrm{C}=\mathrm{O}$ karbonil. Gugus fungsi yang mewakili puncak khas $\mathrm{CO}_{3}$ juga terjadi pergeseran yaitu gugus fungsi $\mathrm{C}=\mathrm{O}$ stretching, gugus fungsi $\mathrm{C}-\mathrm{O}$ stretching, gugus fungsi $\mathrm{C}-\mathrm{N}$ dan gugus fungsi $\mathrm{C}-\mathrm{C}$. 
Terjadinya pergeseran pada puncak penyerapan umumnya menunjukkan adanya interaksi antara zat warna metanil yellow dengan biosorben (Zein et al., 2015). Pergeseran angka gelombang yang tidak signifikan dapat mengindikasikan bahwa telah terjadinya interaksi antara molekul zat warna dengan gugus aktif yang terdapat pada biosorben. Berdasarkan interpretasi spektrum FTIR di atas dapat disimpulkan bahwa gugusgugus fungsi dalam cangkang pensi berperan aktif dalam proses penyerapan zat warna metanil yellow seperti gugus karboksil, karbonil, amina dan karbonat.

Gambar 2 (a) adalah gambar SEM dari permukaan biosorben yang telah diaktivasi dengan $\mathrm{HNO}_{3}$ (sebelum adsorpsi). Aktivasi dengan $\mathrm{HNO}_{3}$ bertujuan untuk mengoptimalkan adsorpsi, karena proses aktivasi dapat menghilangkan zat pengotor dan untuk membuka poripori biosorben.

Berdasarkan Gambar 2 (a) dapat dilihat bahwa permukaan biosorben memiliki rongga atau pori-pori. Pori-pori tersebut bertindak sebagai media tempat proses adsorpsi MY berlangsung sehingga konsentrasi MY berkurang dalam larutan.

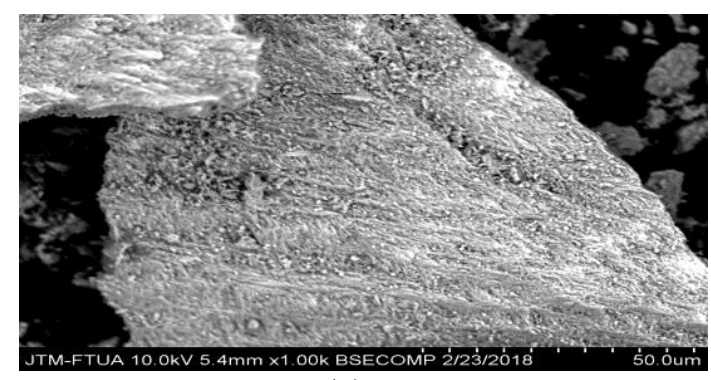

(a)

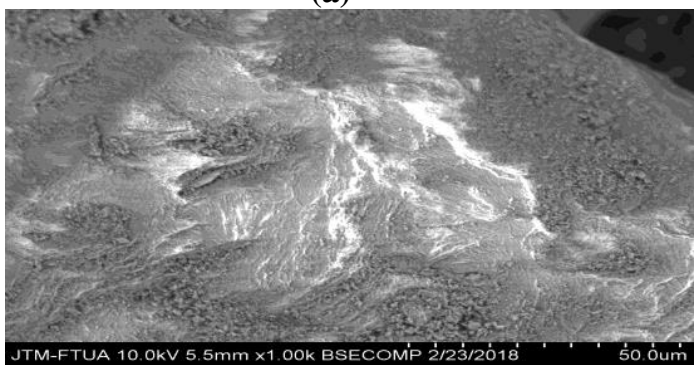

(b)

Gambar 2. Hasil SEM cangkang pensi sebelum penyerapan (a) setelah penyerapan (b).Perbesaran: 1000 kali.

Permukaan biosorben mengalami perubahan setelah biosorpsi MY. Gambar. 2 (b) menunjukkan rongga / pori diisi oleh molekul zat warna dan permukaan menjadi halus karena permukaan biosorben tertutup oleh lapisan homogen dari molekul MY.Hal ini membuktikan bahwa biosorben cangkang pensi telah menyerap zat warna metanil yellow dalam larutan (Fauzia et al., 2015).

\subsection{Analisis nilai pH titik muatan nol $\left(\mathrm{pH}_{\mathrm{pzc}}\right)$}

Nilai $\mathrm{pH}_{\mathrm{pzc}}$ penting dipelajari karena terkait dengan muatan permukaan biosorben yang mempengaruhi mekanisme adsorpsi MY. Adsorpsi anion disukai pada $\mathrm{pH}<\mathrm{pH}_{\mathrm{pzc}}$ sementara adsorpsi kation disukai pada $\mathrm{pH}>$ $\mathrm{pH}_{\mathrm{pzc}}$ (Sadaf and Bhatti, 2014).
Nilai $\mathrm{pH}_{\mathrm{pzc}}$ dari cangkang pensi adalah 7.4 seperti yang dapat dilihat pada Gambar 3. Pada nilai $\mathrm{pH}$ ini, cangkang pensi memiliki muatan nol atau tidak memiliki muatan positif maupun negatif. Pada $\mathrm{pH}>\mathrm{pH}_{\mathrm{pzc}}$, proses adsorpsi sulit terjadi. Hal ini dikarenakan cangkang pensi memiliki muatan negatif yang menyebabkan adanya gaya tolakan elektrostatik antara permukaan biosorben dan molekul MY. Sedangkan pada $\mathrm{pH}<\mathrm{pH}_{\mathrm{pzc}}$, proses adsorpsi berlangsung dengan optimal karena permukaan cangkang pensi memiliki muatan positif yang menyebabkan tarikan elektrostatik yang kuat antara permukaan cangkang pensi dengan molekul MY (Sadaf and Bhatti, 2014).

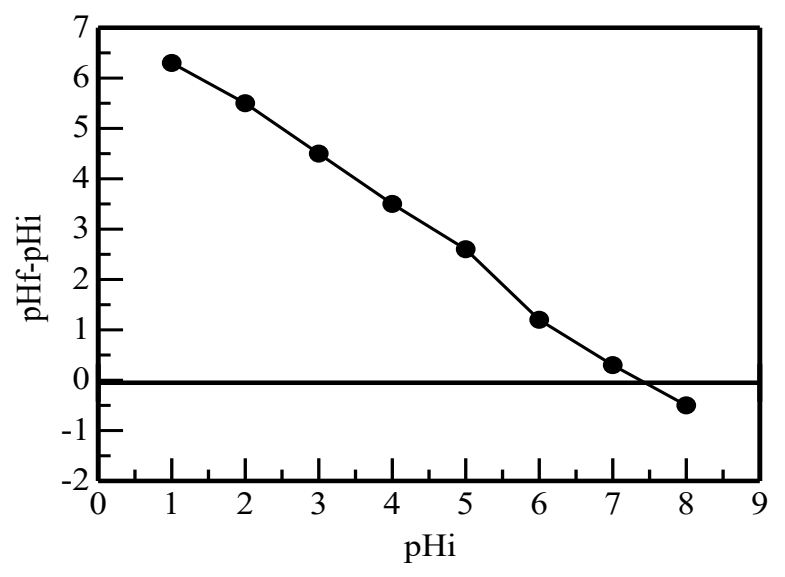

Gambar 3. Kurva $\mathrm{pH}_{\mathrm{pzc}}$ cangkang pensi

Gugus sulfonat yang terdapat dalam zat warna metanil yellow menunjukkan sifat anionik dari MY dalam suasana asam. Sehingga dari nilai $\mathrm{pH}_{\mathrm{pzc}}$ yang diperoleh dapat diperkirakan penyerapan zat warna metanil yellow oleh cangkang pensi yaitu optimum pada $\mathrm{pH}$ yang rendah yaitu pada $\mathrm{pH}<7.4$. Beberapa penelitian mengenai pemanfaatan limbah perikanan untuk adsorpsi zat warna yang bersifat anionik dalam suasana asam juga telah dilaporkan. Salah satunya penelitian yang dilakukan oleh Ribeiro et al (2015) menunjukkan penyerapan zat warna reactive blue $5 \mathrm{G}$ oleh tulang ikan optimum pada $\mathrm{pH}$ dibawah nilai $\mathrm{pH}_{\mathrm{pzc}}(\mathrm{pH}<7,6)$ yaitu $\mathrm{pH}$ 2 (Ribeiro et al., 2015).

\subsection{Pengaruh pH terhadap kapasitas penyerapan metanil yellow}

Pengaruh nilai $\mathrm{pH}$ larutan zat warna merupakan faktor terpenting yang mengontrol proses biosorpsi. $\mathrm{pH}$ sistem mempengaruhi sifat permukaan biosorben, mekanisme ionisasi atau disosiasi molekul zat warna dan juga mempengaruhi interaksi elektrostatik antara permukaan biosorben dan molekul adsorbat (Fauzia et al., 2015; Zein et al., 2015). Pengaruh pH larutan pada adsorpsi zat warna metanil yellow diselidiki dalam rentang pH 3 sampai 8.

Kapasitas adsorpsi optimal adalah $0,130 \mathrm{mg} / \mathrm{g}$ pada pH 4 seperti yang dapat dilihat pada Gambar 4 . Kapasitas adsorpsi awalnya meningkat dari $0,110 \mathrm{mg} / \mathrm{g}$ menjadi $0,130 \mathrm{mg} / \mathrm{g}$ pada $\mathrm{pH} 3-4$. Pada $\mathrm{pH}$ yang lebih tinggi, terjadi penurunan kapasitas adsorpsi dari 0,130 $\mathrm{mg} / \mathrm{g}$ menjadi $0,001 \mathrm{mg} / \mathrm{g}$ pada $\mathrm{pH} 4$ hingga $8 . \mathrm{pH}$ 
larutan sangat mempengaruhi interaksi elektrostatik antara permukaan biosorben dan molekul zat warna. Pada $\mathrm{pH}$ rendah, ada peningkatan ion $\mathrm{H}^{+}$yang akan mendorong gaya tarik elektrostatik dengan anion MY sehingga kapasitas adsorpsi meningkat. Sementara pada $\mathrm{pH}$ yang lebih tinggi terjadi peningkatan ion $\mathrm{OH}^{-}$. Kehadiran ion $\mathrm{OH}^{-}$menjadi pesaing baru yang akan bersaing dengan anion MY untuk mengisi situs aktif. Sehingga terjadi tolakan elektrostatik antara permukaan biosorben dan anion zat warna menyebabkan penurunan kapasitas adsorpsi (Singh, 2006).

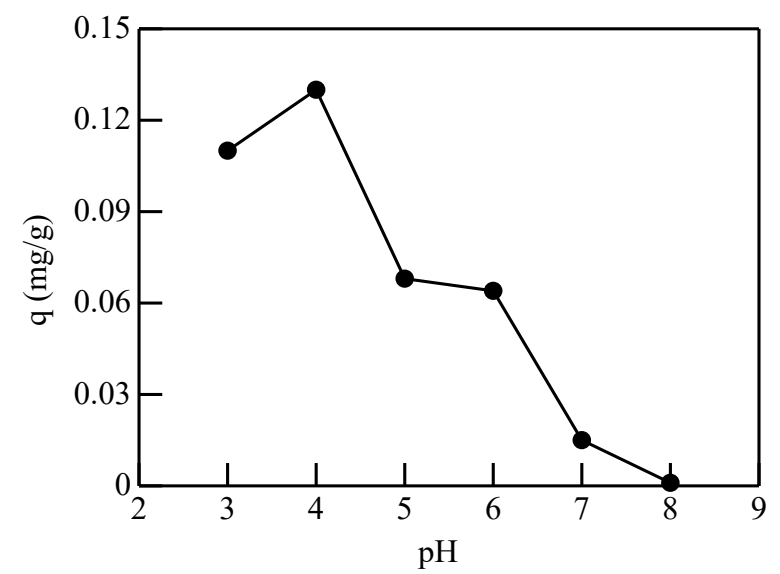

Gambar 4. Pengaruh $\mathrm{pH}$ terhadap kapasitas adsorpsi zat warna metanil yellow oleh cangkang pensi: konsentrasi $15 \mathrm{mg} / \mathrm{L}$; massa biosorben $0,1 \mathrm{~g}$; waktu kontak 90 menit; kecepatan pengadukan $100 \mathrm{rpm}$.

Nilai $\mathrm{pH}$ optimum pada penelitian ini dicapai pada $\mathrm{pH}$ 4. Hal ini sesuai dengan nilai $\mathrm{pH}_{\mathrm{pzc}}\left(\mathrm{pH}_{\mathrm{pzc}}=7,4\right)$, dimana pada $\mathrm{pH}<\mathrm{pH}_{\mathrm{pzc}}$, permukaan cangkang pensi didominasi oleh ion $\mathrm{H}^{+}$yang menyebabkan tarikan elektrostatik yang kuat antara permukaan cangkang pensi dengan anion MY sehingga adsorpsi MY oleh cangkang pensi optimal terjadi pada $\mathrm{pH}$ rendah. Hasil penelitian yang sama juga dilaporkan untuk adsorpsi zat warna metanil yellow menggunakan Bottom Ash dan De-oiled Soya dengan $\mathrm{pH}$ optimum diperoleh pada $\mathrm{pH} 2$ (Mittal et al., 2008). Hasil yang sama juga diperoleh dari penelitian yang dilakukan oleh Tural et al (2015) tentang adsorpsi zat warna metanil yellow dengan $\mathrm{pH}$ optimum yang dicapai pada 4 (Tural et al., 2015).

\subsection{Pengaruh konsentrasi terhadap kapasitas penyerapan zat warna metanil yellow}

Proses adsorpsi dipengaruhi oleh konsentrasi adsorbat (zat warna) karena konsentrasi awal zat warna memberikan kekuatan pendorong dalam proses transfer molekul pewarna antara fase cair dan padat sehingga mempengaruhi interaksi antara adsorben dan adsorbat (Almeida et al., 2017). Pengaruh konsentrasi MY pada proses biosorpsi dipelajari dalam rentang 15-150 mg/L pada kondisi $\mathrm{pH}$ optimal ( $\mathrm{pH} 4)$. Gambar. 5 menunjukkan bahwa penyerapan optimum zat warna MY oleh cangkang pensi tercapai pada konsentrasi 100 $\mathrm{mg} / \mathrm{L}$ dengan kapasitas adsorpsi 1,657 mg/L.

Kapasitas adsorpsi yang meningkat seiring meningkatnya konsentrasi zat warna disebabkan oleh meningkatnya interaksi elektrostatik antara molekul- molekul MY dan situs aktif pada permukaan cangkang pensi. Selain itu, meningkatnya kapasitas adsorpsi disebabkan oleh jumlah situs aktif untuk berinteraksi dengan molekul MY yang tersedia cukup untuk mengakomodasi jumlah zat warna yang cenderung meningkat. Efisiensi penyerapan zat warna tergantung pada konsentrasi awal zat warna. Pada konsentrasi tinggi akan menghasilkan kekuatan pendorong yang lebih tinggi dari gradien konsentrasi. Kekuatan pendorong mempengaruhi kecepatan difusi pewarna dari larutan ke biosorben (Zein et al., 2015).

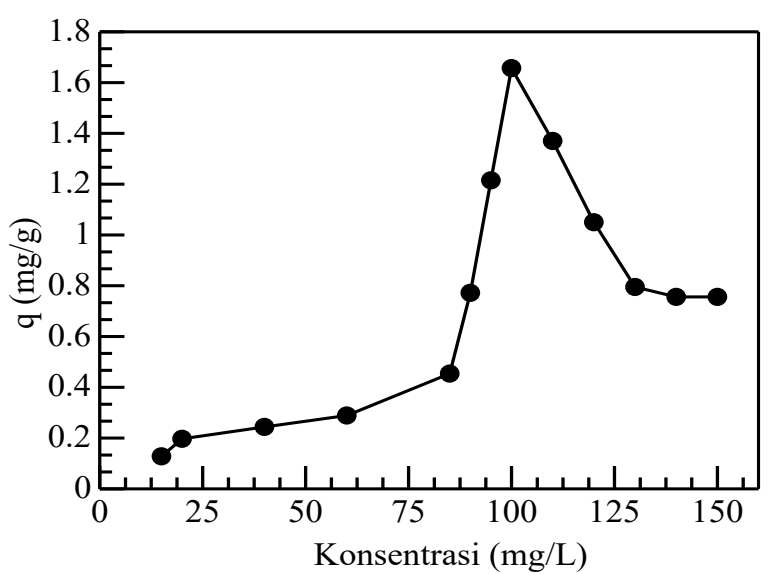

Gambar 5. Pengaruh konsentrasi terhadap kapasitas adsorpsi zat warna metanil yellow oleh cangkang pensi: $\mathrm{pH} 4$; massa biosorben $0,1 \mathrm{~g}$; waktu kontak 90 menit; kecepatan pengadukan $100 \mathrm{rpm}$.

Pada konsentrasi yang lebih tinggi, terjadi penurunan kapasitas adsorpsi karena banyak molekul zat warna tidak terserap yang disebabkan oleh jumlah situs aktif yang tidak sebanding dengan jumlah adsorbat sehingga sisi aktif biosorben mengalami kejenuhan (Chaidir et al., 2015a; Saha et al., 2012). Hasil penelitian yang dilakukan oleh (Isiuku and Onyeokoro, 2018) mengenai adsorpsi zat warna metanil yellow oleh membran kulit telur menunjukkan peningkatan konsentrasi sebanding dengan kapasitas adsorpsi dengan konsentrasi optimum $100 \mathrm{mg} / \mathrm{L}$ (Isiuku and Onyeokoro, 2018).

\subsection{Isoterm adsorpsi}

Penentuan kesetimbangan adsorpsi dengan model isoterm adsorpsi merupakan pendekatan yang sangat penting untuk menggambarkan bagaimana adsorbat didistribusikan antara fase cair dan padat. Penentuan tipe isoterm adsorpsi bertujuan untuk mengetahui proses adsorpsi yang terjadi antara cangkang pensi sebagai adsorben dan zat warna metanil yellow sebagai adsorbat dalam kesetimbangan pada suhu konstan (Zein et al., 2015).

Gambar 6 (a) dan 6 (b) menunjukkan bahwa isoterm Langmuir lebih sesuai untuk proses adsorpsi zat warna metanil yellow oleh cangkang pensi. Hal ini dapat dilihat dari nilai koefisien determinasi $\left(\mathrm{R}^{2}\right)$ dari persamaan linear isoterm Langmuir yang mendekati 1 (lebih besar) dibandingkan persamaan linear isoterm Freundlich. Ini menunjukkan bahwa proses biosorpsi zat warna metanil yellow terjadi secara kimia dengan adanya ikatan antara situs aktif pada permukaan biosorben yang tersebar 
secara homogen dengan membentuk suatu lapisan monolayer (Sadaf and Bhatti, 2014).

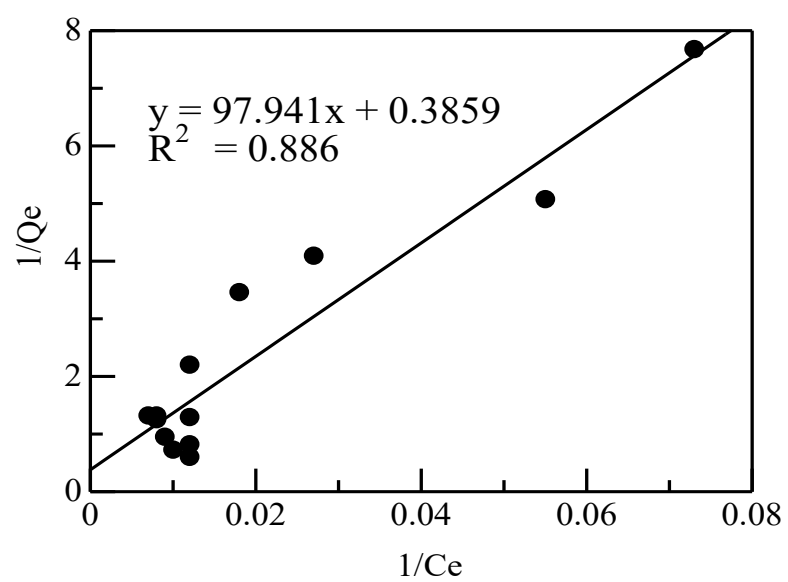

(a)

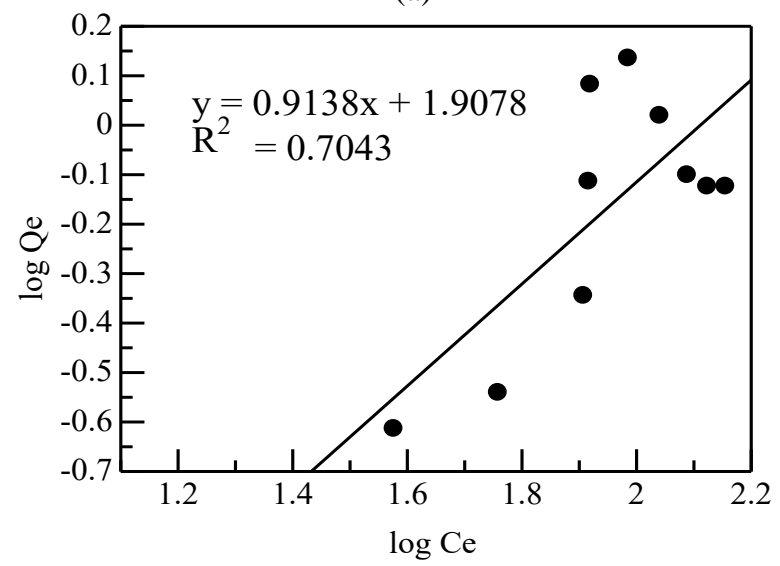

(b)

Gambar 6. (a) persamaan linear isoterm Langmuir dan (b) persamaan linear isoterm Freundlich untuk penyerapan zat warna metanil yellow.

Nilai koefisien determinasi $\left(\mathrm{R}^{2}\right)$, kapasitas penyerapan maksimum $\left(\mathrm{Q}_{\mathrm{m}}\right)$, konstanta kesetimbangan (K), dan afinitas adsorpsi (1/n) dapat dilihat pada Tabel 1. Nilai-nilai tersebut dihitung dari nilai slope dan intersep persamaan linear isoterm Langmuir dan Freundlich.

\section{Tabel 1.}

Koefisien Isoterm Langmuir dan Freundlich pada penyerapan zat warna metanil yellow menggunakan cangkang pensi

\begin{tabular}{llllll}
\hline \multicolumn{2}{l}{ Isoterm Langmuir } & \multicolumn{4}{c}{ Isoterm Freundlich } \\
\hline $\mathrm{q}_{\mathrm{m}}$ & $\mathrm{K}_{\mathrm{L}}$ & $\mathrm{R}^{2}$ & $\mathrm{~K} F$ & $1 / \mathrm{n}$ & $\mathrm{R}^{2}$ \\
$(\mathrm{mg} / \mathrm{g})$ & $(\mathrm{L} / \mathrm{mg})$ & & & \\
2,591 & 0,00394 & 0,886 & 0,012 & 0,913 & 0,7043 \\
\hline
\end{tabular}

Nilai parameter kesetimbangan $\left(\mathrm{R}_{\mathrm{L}}\right)$ menunjukkan tingkat kesesuaian adsorben terhadap adsorbat yang digunakan untuk menunjukkan apakah adsorpsi berlangsung dengan baik (menguntungkan) atau tidak (Inyinbor et al., 2015). Pada penelitian ini nilai $\mathrm{R}_{\mathrm{L}}$ berkisar antara 0,628 hingga 0,944 dimana nilai tersebut berada pada kondisi $0<\mathrm{R}_{\mathrm{L}}<1$. Berdasarkan nilai $\mathrm{R}_{\mathrm{L}}$ tersebut dapat disimpulkan bahwa proses adsorpsi zat warna metanil yellow oleh cangkang pensi berlangsung dengan baik (favorable). Penelitian yang sama mengenai penyerapan zat warna anionik tartrazine oleh karbon aktif Lantana camara menunjukkan nilai $\mathrm{R}_{\mathrm{L}}$ berada pada rentang 0-1 yang menunjukkan proses adsorpsi yang berlangsung baik (menguntungkan) (Gautam et al., 2015).

\section{Kesimpulan}

Cangkang pensi dapat digunakan sebagai biosorben zat warna metanil yellow pada kondisi optimum diperoleh pada $\mathrm{pH} 4$, konsentrasi $100 \mathrm{mg} / \mathrm{L}$, massa $0,1 \mathrm{~g}$, waktu kontak 90 menit dan kecepatan pengadukan 100 rpm. Adsorpsi isoterm mengikuti model isoterm Langmuir dengan kapasitas adsorpsi maksimum $\left(\mathrm{q}_{\mathrm{m}}\right)$ adalah 2,591 mg/g. Nilai parameter kesetimbangan menunjukkan proses adsorpsi zat warna metanil yellow berlangsung dengan baik.

\section{Ucapan terima kasih}

Penulis mengucapkan terima kasih kepada Direktorat Jenderal Pendidikan Tinggi, Kementerian Riset dan Pendidikan Tinggi Republik Indonesia yang telah mendanai penelitian ini sesuai dengan nomor kontrak: 050/SP2H/LT/DRPM/2018.

\section{Daftar pustaka}

Albroomi, H.I., Elsayed, M.A., Baraka, A., Abdelmaged, M.A., 2017. Batch and fixed-bed adsorption of tartrazine azo-dye onto activated carbon prepared from apricot stones. Appl. Water Sci. 7, 2063-2074.

Alencar, W.S., Acayanka, E., Lima, E.C., Royer, B., de Souza, F.E., Lameira, J., Alves, N., 2012. Application of Mangifera indica (mango) seeds as a biosorbent for removal of Victazol Orange 3R dye from aqueous solution and study of the biosorption mechanism. Chem. Eng. J. 209, 577-588.

Almeida, J.M.F., Oliveira, É.S., Silva, I.N., De Souza, S.P.M.C., Fernandes, N.S., 2017. Adsorption of erichrome black $\mathrm{T}$ from aqueous solution onto expanded perlite modified with orthophenanthroline. Rev. Virtual Quim. 9, 502-513.

Benkhaya, S., Harfi, S. El, Harfi, A. El, 2017. Classifications, properties and applications of textile dyes: A review. Appl. J. Environ. Eng. Sci. 3, 311320 .

Chaidir, Z., Furqani, F., Zein, R., Munaf, E., 2015a. Utilization of Annona muricata L . seeds as potential adsorbents for the removal of rhodamine B from aqueous solution. J. Chem. Pharm. Res. 7, 879-888.

Chaidir, Z., Zein, R., Sagita, D.T., Munaf, E., 2015b. Bioremoval of methyl orange dye using durian fruit (Durio zibethinus) Murr seeds as biosorbent. J. Chem. Pharm. Res. 7, 589-599.

Contreras, E., Sepúlveda, L., Palma, C., 2012. Valorization of agroindustrial wastes as biosorbent for the removal of textile dyes from aqueous solutions. Int. J. Chem. Eng. 2012.

Daniel, M., Luna, G.D., Flores, E.D., Angela, D., Genuino, D., Futalan, C.M., Wan, M., 2013. 
Adsorption of Eriochrome Black T ( EBT ) dye using activated carbon prepared from waste rice hulls Optimization, isotherm and kinetic studies. J. Taiwan Inst. Chem. Eng. 44, 646-653.

Djelloul, C., Hamdaoui, O., 2015. Dynamic adsorption of methylene blue by melon peel in fixed-bed columns. Desalin. Water Treat. 56, 2966-2975.

Elamari, L., Areibat, M., Kamari, A., 2017. Razor Clam (Ensis directus) Shell as a Low-cost Adsorbent for the Removal of Congo Red and Rhodamine B Dyes from Aqueous Solution, in: International Conference on Education, Mathematics and Science 2016 (ICEMS2016) in Conjunction with the 4th International Postgraduate Conference on Science and Mathematics 2016 (IPCSM2016). American Institute of Physic, Malaysia.

Fauzia, S., Furqani, F., Zein, R., Munaf, E., 2015. Adsorption and reaction kinetics of tatrazine by using Annona muricata L seeds. J. Chem. Pharm. Res. 7, 573-582.

Gautam, R.K., Gautam, P.K., Banerjee, S., Rawat, V., Soni, S., Sharma, S.K., Chattopadhyaya, M.C., 2015. Removal of tartrazine by activated carbon biosorbents of Lantana camara: Kinetics, equilibrium modeling and spectroscopic analysis. J. Environ. Chem. Eng. 3, 79-88. https://doi.org/10.1016/j.jece. 2014.11.026

Gupta, V.K., Suhas, 2009. Application of low-cost adsorbents for dye removal - A review. J. Environ. Manage. 90, 2313-2342. https://doi.org/10.1016/ j.jenvman.2008.11.017

Inyinbor, A.A., Adekola, F.A., Olatunji, G.A., 2015. Adsorption of Rhodamine $\mathrm{B}$ dye from aqueous solution on Irvingia gabonensis biomass: Kinetics and thermodynamics studies. South African J. Chem. $68,115-125$.

Isiuku, B.O., Onyeokoro, J.O., 2018. Batch Biosorption of Metanil Yellow from Aqueous Solution on Egg Membrane: Kinetics and Mechanism. Int. J. Chem. Mater. Environ. Res. 5, 155-164.

Islam, K.N., Zuki, A.B.Z., Ali, M.E., Hussein, B.M.., Noordin, M.M., Loqman, M.Y., Wahid, H., Hakim, M.A., Hamid, S.B.A., 2012. Facile synthesis of calcium carbonate nanoparticles from cockle shells. J. Nanomater. 2012.

Jeyajothi, K., 2014. Removal of dyes from textile wastewater using Orange peel as adsorbent. J. Chem. Pharm. Sci. 161-163.

Khedr, S.A., Shouman, M.A., Attia, A.A., 2013. Adsorption studies on the removal of cationic dye from shrimp shell using chitin. Biointerface Res. Appl. Chem. 3, 507-519.

Messaoudi, E.N., Elkhomri, M., Dbik, A., Bentahar, S., Lacherai, A., Bakiz, B., 2016. Biosorption of Congo red in a fixed-bed column from aqueous solution using jujube shell: Experimental and mathematical modeling. J. Environ. Chem. Eng. 4, 3848-3855.

Mittal, A., Gupta, V.K., Malviya, A., Mittal, J., 2008. Process development for the batch and bulk removal and recovery of a hazardous, water-soluble azo dye (Metanil Yellow) by adsorption over waste materials (Bottom Ash and De-Oiled Soya). J. Hazard. Mater. 151, 821-832.
Ravi, T., Stanley, A.L., Narendrakumar, G., Rao, A.K.S., 2015. Extraction of chitosan from prawn shell waste and its application in dye decolorization. J. Chem. Pharm. Res. 7, 695-703.

Reddy, M.C.., Sivaramakrishna, L., Reddy, A.., 2012. The use of an agricultural waste material, Jujuba seeds for the removal of anionic dye ( Congo red ) from aqueous medium. J. Hazard. Mater. 203-204, 118-127.

Rehman, R., Mahmud, T., Anwar, J., 2012. Biosorptive Treatment of Acid Yellow-73 Dye Solution with Chemically Modified Eugenia jambolana Seeds. J. Chemical Soc. Pakistan 34, 1120-1126.

Ribeiro, C., Scheufele, F.B., Espinoza-Quiñones, F.R., Módenes, A.N., da Silva, M.G.., Vieira, M.G.., Borba, C.., 2015. Characterization of Oreochromis niloticus fish scales and assessment of their potential on the adsorption of reactive blue $5 \mathrm{G}$ dye. Colloids Surfaces A Physicochem. Eng. Asp. 482, 693-701.

Saba, B., Christy, A.D., Jabeen, M., 2016. Kinetic and Enzymatic Decolorization of Industrial Dyes Utilizing Plant-Based Biosorbents: A Review. Environ. Eng. Sci. 33, 601-614.

Sadaf, S., Bhatti, H.N., 2014. Batch and fixed bed column studies for the removal of Indosol Yellow BG dye by peanut husk. J. Taiwan Inst. Chem. Eng. 45, 541-553.

Saha, P., Chakraborty, S., Chowdhury, S., 2012. Batch and continuous (fixed-bed column) biosorption of crystal violet by Artocarpus heterophyllus (jackfruit) leaf powder. Colloids Surfaces B Biointerfaces 92, $262-270$.

Singh, T.S., 2006. Investigations on reduction of colour from pulp and paper mill effluent by activated coconut jute carbon. J. Water Supply Res. Technol. AQUA 55, 57-64.

Sivakumar, P., Palanisamy, P.N., 2009. Packed bed column studies for the removal of Acid blue 92 and Basic red 29 using non-conventional adsorbent. Indian J. Chem. Technol. 16, 301-307.

Sulyman, M., Namiesnik, J., Gierak, A., 2017. Low-cost Adsorbents Derived from Agricultural By-products / Wastes for Enhancing Contaminant Uptakes from Wastewater : A Review. Polish J. Environ. Stud. 26, 479-510. https://doi.org/10.15244/pjoes/66769

Sushmita, B., Chattopadhyaya, M.C., 2017. Adsorption characteristics for the removal of a toxic dye , tartrazine from aqueous solutions by a low cost agricultural by-product. Arab. J. Chem. 10, S1629S1638.

Tural, S., Tarhan, T., Tural, B., 2015. Removal of hazardous azo dye Metanil Yellow from aqueous solution by cross-linked magnetic biosorbent; equilibrium and kinetic studies. Desalin. Water Treat. $1-10$.

Zein, R., Astuti, A.W., Wahyuni, D., Furqani, F., Munaf, E., 2015. Removal of Methyl Red from Aqueous Solution by Neplhelium lappaceum. Res. J. Pharm. , Biol. Chem. Sci. 6, 86-97.

Zein, R., Suhaili, R., Earnestly, F., Indrawati, Munaf, E., 2010. Removal of $\mathrm{Pb}(\mathrm{II}), \mathrm{Cd}(\mathrm{II})$ and $\mathrm{Co}(\mathrm{II})$ from aqueous solution using Garcinia mangostana L. fruit shell. J. Hazard. Mater. 181, 52-56. 
Zein, R., Syukri, S., Muhammad, M., Pratiwi, I., Yutaro, D.R., 2018. The ability of pensi (Corbicula moltkiana) shell to adsorb Cd ( II ) and Cr ( VI ) ions, in: AIP Conference Proceedings. https://doi.org/

\subsection{3/1.5064096}

Zeswita, A., Safitri, E., 2015. Karakterisasi morfomerik pensi (Corbicula moltkiana Prime) pada dua ekosistem yang berbeda. BioCONCETTA 1, 49-58. 